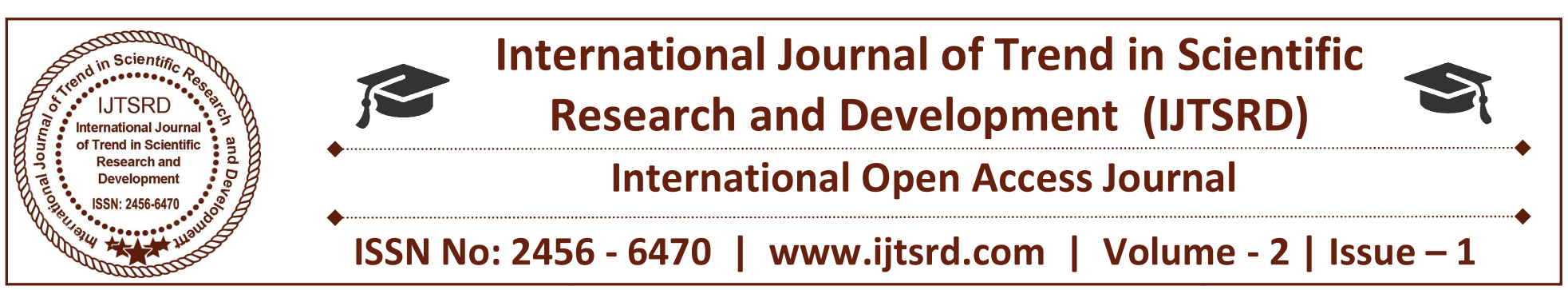

\title{
Marketing Mix Strategies of Soft Drink Producers in Anambra State, Nigeria
}

\author{
Okwuchukwu Marcus, Anyasor, Ph.D \\ Department of Marketing, Chukwuemeka Odumegwu University, \\ Anambra State, Nigeria
}

\section{ABSTRACT}

The study aimed to investigate the marketing mix strategies employed by soft drink producers in Anambra State and to assess the impact of such strategies on their performance. Ninety respondents were judgementally selected and sampled. Questionnaire was used to gather the study data analysed on frequencies, percentages and KruskalWallis one-way ANOVA. Results showed that promotion consisting sponsorship in sports and entertainment, diversification, introduction of new brands/products, aggressive advertising and price reduction are the most frequently used marketing-mix strategies. Results also agreed that the soft drink producers in Anambra State change their marketing mix and often too for reasons of making their products new and attractive, offering at customers' asking price, competition in the market, grow market share, and profit. Results of the hypotheses testing indicated significance mean difference in the marketing-mix frequently used by these producers but, there is no significant mean difference on how often those change their strategies. Hypotheses tests confirm that these producers change mix strategy to grow market vis-à-vis other objectives. Overall, the tests showed marketingmix strategies have significant impact on the performance of all the soft drink producers in Anambra State.

Keywords: marketing-mix strategy, soft-drink marketing, marketing promotion, Anambra State

\section{INTRODUCTION}

Background of the Study
Today's marketing environment dynamic and hypercompetitive that organizations employ varied strategies to survive. However, marketing practices and strategies are borne out of specific situation and variables: the environment; the nature of the market served; the growth stage of the organization; the types of products/services offered; and the quality of organization management (Hogarth-Scoth, Watson \& Wilson, 1996). In order to survive and effectively adapt to the changing environment, as well as achieve their set marketing goals and objectives therefore, firms design different marketing strategies. Marketing-mix is one of such contemporary marketing strategies. Generally, marketing strategy deals with adapting the marketing-mix elements - product, price, placement and promotion to environmental factors. This is because of interplay of mix elements and the environmental factors that impact on them (Schnars 1991; Jain 1993; Aristobulo 1997; Mavondo 2000). However, achieving efficient and effective marketing strategy by an organization is seemingly difficult due to the ambiguity and instability of environmental factors (Brownlie \& Spender, 1995).

Launching a product in the market and winning consumers in the initial period is not enough; sustaining market share, even when competition is on the rise is crucial for company long term profitability. But, naturally, consumers have short concentration spans - it does not take long for competitors to come in and modify existing product and snatch away a company's customers. Thus a company may have to work tirelessly in bringing up strategies to sustain its market share. 
Considering that human behaviour is very dynamic, Kotler and Armstrong (2006) posited that marketing mix strategies has to be adjusted on a frequent basis to meet the changing needs of the target group and dynamics of the marketing environment, in other to achieve a firm's set objective.

The target market is a fairly homogenous group of customers to whom a company must appeal in order to survive in business. Appealing to the target market entails using an appropriate combination of marketingmix to satisfy their need, profitably (Pride and Ferrell, 1985). Therefore, the function of the marketing mix is to help develop a package that will not only satisfy the needs of the target, but simultaneously maximize the performance of the organization (www.12manage.com). To achieve these, a company's marketing plan would comprise a detailed analysis of the target market and marketing environment.

\section{Problem of the Study}

The soft-drink producers comprise of firms that make non-alcoholic beverages and carbonated mineral waters or concentrates and syrups for blending of carbonated beverages. This beverage market can be divided into fruit drinks and soft drinks. It can further be subdivided into carbonated and non-carbonated drinks. Cola, lemon and orange drinks are carbonated, while mango drinks come under non-carbonated category. This study is concerned with the companies that produce all the three classes of carbonated (mineral) soft drinks in Anambra State, Nigeria.

In the present times, achieving and retaining a dominant position in the market has become very stressful for these producers due to influx of alternative brands as well as the attendant aggressive competition and increasing customer demand. To improve and sustain their market share and profitability drive their efforts as a result. It will therefore interest to understand the marketing mix variables and strategies that soft drink producers in Anambra state employ to satisfy their clients' needs and wants and how they achieve this.

\section{Objectives of the Study}

This study in effect seeks to identify measure, analyse and establish which marketing mix strategies that are mostly used in the industry in the study area; and their effect on their market share and corporate performance. It is expected that the outcome of this study will give various interest groups particularly the players in the soft drink industry insight of the operations of industry in study area; how to manipulate marketing mix to advantage as well as acquaint the reader with the basic knowledge on the science of combining the various marketing elements for sustainable and profitable marketing.

\section{LITERATURE REVIEW}

Numerous definitions of marketing strategy in the literature, including that of Li, Kinman, Duan and Edwards (2000), reflecting different perspectives are of the consensus that marketing strategy provides the avenue for utilizing the resources of an organization in order to achieve its set goals and objectives. McCarthy and Perrault (1984) and Pride and Ferrell (1985) surmised marketing strategy as a broad spectrum of what a firm will do in some market including selecting and analysing a target market and creating and maintaining an appropriate controllable marketing mix variables - product, distribution, promotion and price to appeal and deliver satisfaction these prospects. In this instance, a marketing strategy forms the core of a successful marketing plan. It articulates a plan for the best use of the organisation's resources and advantages to meet its objectives.

When choosing a target market, marketing managers try to evaluate possible markets to estimate how entering they would affect the firm's sales, costs and profits. They also attempt to determine, if the organisation has the resources to produce a marketing mix that meets the needs of the particular target market and whether satisfying those needs is consistent with the firms overall objectives. They also analyse the size and number of competitors already in the possible target market. The target market therefore, is a group of persons for whom a firm creates and maintains a marketing mix that specifically fits their needs and preferences.

In order to formulate and implement efficient and effective marketing strategies, firms seek thorough and continuous understanding of the relevant environment that impacts on their marketing plan. Developing an organization's marketing strategy aims to establish, build, defend and maintain its competitive advantage (McDonald, 1992). Managerial judgment is important in coping with environmental ambiguity and uncertainty in strategic marketing (Brownie and Spender, 1995).

However, Li, Kinman, Duan and Edwards (2000) observed that it is difficult for an organization to 
achieve an efficient and effective marketing strategy as a result of the ambiguity and instability of environmental factors. Many factors are noted to impinge on organizational managers' ability to design and implement efficient and effective marketing strategies (McDonald 1992). The fact is that environmental factors generally interact in an astonishing manner and affect the efficiency and effectiveness of managers in strategic marketing issues (McDonald 1989; 1996).

Marketing strategies and tactics are concerned with taking decisions on a number of variables to influence mutually-satisfying exchange transactions and relationships. Typically, marketers, in addition to the conventional 4Ps strategy also apply what Kotler (1986) called mega-marketing among others. Megamarketing describes marketing activity required when it is expedient to manage a firm's external environment (governments, the media, pressure groups, etc.) as well as the marketing variables. Organizational managers in many firms apply the marketing concept, which may be simple or complex. Developing and implementing efficient and effective marketing strategies that incorporate relevant dimensions of the marketing concept involve the organic tasks of selecting a target market to serve and developing an efficient and effective marketing ingredient combination (Johns, 1990).

\section{Operational Concept of Marketing-mix}

Operationalizing the workings of the marketing-mix, thetimes100.co.uk (Retrieved, 2011) observed that when marketing their products, firms need to create a successful mix of the right product, sold at the right price, in the right place, using the most suitable promotion. The product element is the product itself; getting the price right involves examining customer perceptions and rival products as well as manufacturing costs; promotion involves engaging in a range of promotional activities e.g. competitions, product tasting etc., and place involves using the best possible distribution network. Being the focal point of marketing energy, the concern of product is what it means to the customer including its appearance and function identified through market research.

According to thetimes100.co.uk (Retrieved, 2011) the product range and how it is used is a function of the marketing mix. The range may be broadened or a brand may be extended for tactical reasons, such as matching competition or catering for seasonal fluctuations. Alternatively, a product may be repositioned to make it more acceptable for a new group of consumers as part of a long-term plan. It further posited that, while the other aspects of the marketing mix incur costs, price is the only one that creates sales revenue. Theoretically, price is really determined by the discovery of what customers perceive is the value of the item on sale. Researching consumers' opinions about pricing is important as it indicates how they value what they are looking for as well as what they want to pay. An organisation's pricing policy usually varies on time and extant circumstances.

Place is concerned with various methods of transporting, storing, and making the goods available to the customer. Akinyele (2010) observed that figures vary widely from product to product but roughly one fifth of the cost of a product goes in getting it to the consumer. Making the right product available at the right place and at the right time implies the application of the right distribution system/method which choice decision depends on a variety of circumstances. Some firms may find it more convenient to deal with the wholesalers who then sell to retailers, while others may prefer to sell directly to retailers or customers (thetimes100.co.uk, Retrieved, 2011). Recent practices have shown that local producers of soft drinks distribute and sell their product to wholesalers, retailers and, directly to the ultimate consumers.

The promotion aspect of marketing-mix is the business of communicating with consumers. Akinyele (2010) posited that promotion provides information that assists consumers in making decision to purchase a product or service. According to Ekerete (2001), the cost associated with promotion or advertising goods and services often represents a sizeable proportion of the overall cost of producing an item. However, successful promotion increases sales so that advertising and other costs are spread over a larger output. Though increased promotional activity is often a sign of a response to a problem such as competitive activity, it enables an organisation to develop and build up a succession of messages and can be extremely cost-effective. Overall, the use marketing mix model can be helpful to a company in deciding how to take a new offering to market and/or to test an existing marketing strategy.

\section{METHODOLOGY}

Three soft drink competitors in Anambra State: Nigerian Bottling Company Plc, Pepsi Company Plc and Nigerian Breweries Plc were studied. 30 respondents (only senior staff) each of the three firms were judgementally selected. The questionnaire used 
for the study was pre-tested in the neighbouring Owerri, Imo State, to avoid any possible influence on trial respondents.

Distribution frequency and percentage were used to analyse the sample characteristics, while the mean was used to answer the research questions. Kruskal-Wallis one-way Analysis of Variance (ANOVA) on ranks was used to analyze differences in means between groups. 1 . ANOVA on ranks means that a standard analysis of variance is calculated on the rank-transformed data. Kruskal-Wallis test is favoured in this study because of its ability to test more than two sub-groups as we have in this study, i.e. to determine whether three or more independent groups are the same or different on some variables of interest when ordinal, interval or ratio leveb. of data is involved. Since it is a non-parametric method, the Kruskal-Wallis test does not assume a normal population, unlike the analogous one-way analysis $o B$. variance. However, the test does assume an identicallyshaped and scaled distribution for each group, except for any difference in medians. All analyses were run on SPSS 16 software for windows.

\section{Method}

1. Rank all data from all groups together; i.e., rank the data from 1 to $N$ ignoring group membership. Assign any tied values the average of the ranks they would have received had they not been tied.

2. The test statistic is given by: $K=(N-$ $1 \frac{\left.\sum_{i=1}^{g} n_{i} \check{r}-\breve{\mathrm{r}}\right)^{2}}{\left.\sum_{i=1}^{g} \sum_{j=1}^{n_{i}} r_{i j}-\check{\mathrm{r}}\right)^{2}}$

Where:

- $n_{i}$ is the number of observations in group $i$

- $\quad r_{i j}$ is the rank (among all observations) of observation $j$ from group $i$

- $\quad N$ is the total number of observations across all groups

- $\quad \check{\mathrm{r}}_{i}=\frac{\sum_{j=1}^{n_{i}} r_{i j}}{n_{i}}$

- $\quad \check{\mathrm{r}}=1 / 2(\mathrm{~N}+1)$ is the average of all the $r_{i j}$.

Notice that the denominator of the expression for $K$ is exactly

$(N-1) N(N+1) / 12$ and $\check{\mathrm{r}}=\frac{N+1}{2}$. Thus

$$
\begin{aligned}
& \mathrm{K}=\frac{12}{N(N+1)} \sum_{i=1}^{g} n_{i}\left(\check{\mathrm{r}}_{i}-\frac{N+1}{2}\right) \\
& =\frac{12}{N(N+1)} \sum_{i=1}^{g} n_{i} \check{\mathrm{r}}_{i}^{2}\left(\check{\mathrm{r}}_{i}-3(N+1)\right.
\end{aligned}
$$

Notice that the last formula only contains the squares of the average ranks.

A correction for ties can be made by dividing $K$ by $1-\frac{\sum_{i=1}^{G}\left(t_{i}^{3}-t_{i}\right.}{N^{3}-N}$, where $G$ is the number of groupings of different tied ranks, and $t_{i}$ is the number of tied values within group $i$ that are tied at a particular value. This correction usually makes little difference in the value of $\mathrm{K}$ unless there are a large number of ties.

Finally, the p-value is approximated by $\operatorname{Pr}\left(X_{g-1}^{2} \geq \mathrm{K}\right)$. If some $n_{i}$ values are small.

(i.e., less than 5) the probability distribution of $\mathrm{K}$ can be quite different from this chi-square distribution. If a table of the chi-square probability distribution is available, the critical value of chi-square, can be found by entering the table at $g-1$ degrees of freedom and looking under the desired significance or alpha level. The null hypothesis of equal population means would then be rejected if $K \geq X_{a: g-1}^{2}$. Appropriate multiple comparisons would then be performed on the group means.

\section{RESULTS AND INTERPRETATION}

All the questionnaires distributed were duly completed and returned; therefore the 90 samples for the study were used in the analyses. Demographics of the respondents are shown in the Tables 1 below, while others treated the core objectives of this study. 
International Journal of Trend in Scientific Research and Development (IJTSRD) ISSN: 2456-6470

Table 1: Distribution of Responses on Respondent's Demographics

\begin{tabular}{|c|c|c|c|c|c|c|}
\hline & & & Frequency & $\%$ & Valid $\%$ & Cumulative $\%$ \\
\hline & \multirow[t]{3}{*}{ Valid } & Male & 58 & 64.4 & 64.4 & 64.4 \\
\hline \multirow[t]{2}{*}{ Gender } & & Female & 32 & 35.6 & 35.6 & 100.0 \\
\hline & & Total & 90 & 100.0 & 100.0 & \\
\hline \multirow{6}{*}{ Qualification } & \multirow[t]{6}{*}{ Valid } & \multirow{2}{*}{$\begin{array}{l}\text { At least SSCE } \\
\text { OND and equivalent }\end{array}$} & 26 & 28.9 & 28.9 & 28.9 \\
\hline & & & 33 & 36.7 & 36.7 & 65.6 \\
\hline & & HND and equivalent & 26 & 28.9 & 28.9 & 94.4 \\
\hline & & BSc and equivalent & 4 & 4.4 & 4.4 & 98.9 \\
\hline & & PGD and above & 1 & 1.1 & 1.1 & 100.0 \\
\hline & & Total & 90 & 100.0 & 100.0 & \\
\hline & Valid & less than 5 years & 24 & 26.7 & 26.7 & 26.7 \\
\hline & & $5-10$ years & 42 & 46.7 & 46.7 & 73.3 \\
\hline Years & & $11-20$ years & 20 & 22.2 & 22.2 & 95.6 \\
\hline & & Above 20 years & 4 & 4.4 & 4.4 & 100.0 \\
\hline & & Total & 90 & 100.0 & 100.0 & \\
\hline & Valid & Manager & 3 & 3.3 & 3.3 & 3.3 \\
\hline & & Other senior staff & 52 & 57.8 & 57.8 & 61.1 \\
\hline Position & & Junior staff & 35 & 38.9 & 38.9 & 100.0 \\
\hline & & Total & 90 & 100.0 & 100.0 & \\
\hline
\end{tabular}

The above Table 1 shows that $58(64.4 \%)$ respondents were male, while $32(35.6 \%)$ were female, indicating that more males participated in the study. The results also show that most of the respondents were OND holders (36.7\%). This is followed closely by holders of SSCE, and HND/equivalent with same score.

Further, the results on respondents' years of experience indicate that majority of the respondents had worked with their respective employers for at least 5 years and above. While the distribution of positions of responsibility held indicates that only three managers $(3.3 \%)$ responded to the questionnaire. 


\section{Marketing mix strategy most frequently used by soft drink producers in Anambra State}

Table 2: Distribution of Responses on Most Frequently Used Marketing Mix Strategy by the Soft Drink

\section{Producers}

\begin{tabular}{|c|c|c|c|c|c|c|c|}
\hline \multicolumn{2}{|l|}{ Mixes } & \multirow{2}{*}{$\begin{array}{l}\text { Response } \\
\text { Strongly Agree }\end{array}$} & \multirow{2}{*}{$\begin{array}{l}\text { Fre } \\
\text { q. } \\
16\end{array}$} & \multirow{2}{*}{$\begin{array}{l}\% \\
17.8\end{array}$} & \multirow{2}{*}{$\begin{array}{l}\text { Valid \% } \\
17.8\end{array}$} & \multirow{2}{*}{$\begin{array}{l}\text { Cumu.\% } \\
17.8\end{array}$} & \multirow[t]{2}{*}{ Decision } \\
\hline \multirow{6}{*}{$\begin{array}{l}\text { Sports } \\
\text { sponsorship }\end{array}$} & \multirow[t]{5}{*}{ Valid } & & & & & & \\
\hline & & Agree & 45 & 50.0 & 50.0 & 67.8 & Agreement \\
\hline & & Undecided & 6 & 6.7 & 6.7 & 74.4 & \\
\hline & & Disagree & 20 & 22.2 & 22.2 & 96.7 & \\
\hline & & Strongly Disagree & 3 & 3.3 & 3.3 & 100.0 & \\
\hline & & Total & 90 & 100.0 & 100.0 & & \\
\hline \multirow{5}{*}{$\begin{array}{l}\text { Sponsorship of } \\
\text { education }\end{array}$} & \multirow[t]{5}{*}{ Valid } & Agree & 28 & 31.1 & 31.1 & 31.1 & \\
\hline & & Undecided & 40 & 44.4 & 44.4 & 75.6 & Uncertain \\
\hline & & Disagree & 17 & 18.9 & 18.9 & 94.4 & \\
\hline & & Strongly Disagree & 5 & 5.6 & 5.6 & 100.0 & \\
\hline & & Total & 90 & 100.0 & 100.0 & & \\
\hline \multirow{4}{*}{$\begin{array}{l}\text { Entertainment } \\
\text { Sponsorship }\end{array}$} & \multirow[t]{4}{*}{ Valid } & Strongly Agree & 45 & 50.0 & 50.0 & 50.0 & \\
\hline & & Agree & 39 & 43.3 & 43.3 & 93.3 & Strong \\
\hline & & Undecided & 6 & 6.7 & 6.7 & 100.0 & Agreement \\
\hline & & Total & 90 & 100.0 & 100.0 & & \\
\hline \multirow{5}{*}{$\begin{array}{l}\text { Sponsorship in } \\
\text { healthcare }\end{array}$} & \multirow[t]{5}{*}{ Valid } & Strongly Agree & 1 & 1.1 & 1.1 & 1.1 & \\
\hline & & Agree & 25 & 27.8 & 27.8 & 28.9 & Undecided \\
\hline & & Undecided & 50 & 55.6 & 55.6 & 84.4 & \\
\hline & & Disagree & 14 & 15.6 & 15.6 & 100.0 & \\
\hline & & Total & 90 & 100.0 & 100.0 & & \\
\hline \multirow[t]{6}{*}{ Diversification } & Valid & Strongly Agree & 29 & 32.2 & 32.2 & 32.2 & \\
\hline & & Agree & 24 & 26.7 & 26.7 & 58.9 & Agreement \\
\hline & & Undecided & 17 & 18.9 & 18.9 & 77.8 & \\
\hline & & Disagree & 17 & 18.9 & 18.9 & 96.7 & \\
\hline & & Strongly Disagree & 3 & 3.3 & 3.3 & 100.0 & \\
\hline & & Total & 90 & 100.0 & 100.0 & & \\
\hline Introduction of & Valid & Strongly Agree & 47 & 52.2 & 52.8 & 52.8 & \\
\hline \multirow[t]{6}{*}{ new brands } & & Agree & 12 & 13.3 & 13.5 & 66.3 & Agreement \\
\hline & & Undecided & 20 & 22.2 & 22.5 & 88.8 & \\
\hline & & Disagree & 10 & 11.1 & 11.2 & 100.0 & \\
\hline & & Total & 89 & 98.9 & 100.0 & & \\
\hline & Missing & System & 1 & 1.1 & & & \\
\hline & \multicolumn{2}{|l|}{ Total } & 90 & 100.0 & & & \\
\hline Aggressive & Valid & Strongly Agree & 70 & 77.8 & 77.8 & 77.8 & Strong \\
\hline
\end{tabular}


International Journal of Trend in Scientific Research and Development (IJTSRD) ISSN: 2456-6470

\begin{tabular}{|l|l|l|l|l|l|l|l|}
\hline advertising & & Agree & 19 & 21.1 & 21.1 & 98.9 & agreement \\
\hline & & Undecided & 1 & 1.1 & 1.1 & 100.0 & \\
\hline & & Total & $\mathbf{9 0}$ & $\mathbf{1 0 0 . 0}$ & $\mathbf{1 0 0 . 0}$ & & \\
\hline Price reduction & Valid & Strongly Agree & 13 & 14.4 & 14.4 & 14.4 & \\
\hline & & Agree & 40 & 44.4 & 44.4 & 58.9 & Agreement \\
\hline & & Undecided & 21 & 23.3 & 23.3 & 82.2 & \\
\hline & & Disagree & 15 & 16.7 & 16.7 & 98.9 & \\
\hline & & Strongly Disagree & 1 & 1.1 & 1.1 & 100.0 & \\
\hline & & & & & & & \\
\hline & & Total & $\mathbf{9 0}$ & $\mathbf{1 0 0 . 0}$ & $\mathbf{1 0 0 . 0}$ & & \\
\hline & & & & & & & \\
\hline
\end{tabular}

The results in the above table indicate that the respondents were unanimous in agreement about sponsorship of sports and other entertainments, diversification, introduction of new brands of products, aggressive advertising, and price reduction as the most frequently used marketing-mix strategies. While it is uncertain as to whether sponsoring scholarships is frequently used or not, they were however undecided about sponsorship of healthcare services.

\section{How often Soft Drink Producers in Anambra State Change their Marketing Mix}

\section{Table 3: Distribution of Responses on Change of Marketing mix and the Frequency}

\begin{tabular}{|c|c|c|c|c|c|c|}
\hline & & & Frequency & $\%$ & Valid \% & Cumulative $\%$ \\
\hline Change of & \multirow[t]{3}{*}{ Valid } & YES & 87 & 96.7 & 96.7 & 96.7 \\
\hline Marketing & & $\mathrm{NO}$ & 3 & 3.3 & 3.3 & 100.0 \\
\hline $\operatorname{mix}$ & & Total & 90 & 100.0 & 100.0 & \\
\hline \multirow{4}{*}{ Frequency of Change } & \multirow[t]{4}{*}{ Valid } & Not often & 22 & 24.4 & 24.4 & 24.4 \\
\hline & & Often & 54 & 60.0 & 60.0 & 84.4 \\
\hline & & Very often & 14 & 15.6 & 15.6 & 100.0 \\
\hline & & Total & 90 & 100.0 & 100.0 & \\
\hline
\end{tabular}

From the results in the above table, it is clear that majority of the respondents admitted that soft drink producers in the study site change their marketing mix and, often too. 


\section{Reasons for Change in Mix Strategies of Soft Drink Producers in Anambra State}

\begin{tabular}{|c|c|c|c|c|c|c|c|}
\hline \multicolumn{2}{|l|}{ Reason } & \multirow{2}{*}{$\begin{array}{l}\text { Response } \\
\text { Agree }\end{array}$} & \multirow{2}{*}{$\begin{array}{l}\text { Freq. } \\
3\end{array}$} & \multirow{2}{*}{$\begin{array}{l}\% \\
3.3\end{array}$} & \multirow{2}{*}{$\begin{array}{l}\text { Valid \% } \\
3.3\end{array}$} & \multirow{2}{*}{$\begin{array}{l}\text { Cumu. } \\
\%\end{array}$} & \multirow[t]{2}{*}{ Decision } \\
\hline \multirow{5}{*}{$\begin{array}{l}\text { Build-in what } \\
\text { customers want }\end{array}$} & \multirow[t]{5}{*}{ Valid } & & & & & & \\
\hline & & Undecided & 23 & 25.6 & 25.6 & 28.9 & Disagreement \\
\hline & & Disagree & 42 & 46.7 & 46.7 & 75.6 & \\
\hline & & Strongly Disagree & 22 & 24.4 & 24.4 & 100.0 & \\
\hline & & Total & 90 & 100.0 & 100.0 & & \\
\hline \multirow{5}{*}{$\begin{array}{lr}\text { Make } & \text { products } \\
\text { new } & \text { and } \\
\text { attractive } & \end{array}$} & \multirow[t]{5}{*}{ Valid } & Strongly Agree & 27 & 30.0 & 30.0 & 30.0 & \\
\hline & & Agree & 43 & 47.8 & 47.8 & 77.8 & Agreement \\
\hline & & Undecided & 18 & 20.0 & 20.0 & 97.8 & \\
\hline & & Disagree & 2 & 2.2 & 2.2 & 100.0 & \\
\hline & & Total & 90 & 100.0 & 100.0 & & \\
\hline \multirow{7}{*}{$\begin{array}{l}\text { Offer products at } \\
\text { customers' price }\end{array}$} & \multirow[t]{5}{*}{ Valid } & Strongly Agree & 4 & 4.4 & 4.5 & 4.5 & \\
\hline & & Agree & 46 & 51.1 & 51.7 & 56.2 & \\
\hline & & Undecided & 27 & 30.0 & 30.3 & 86.5 & Agreement \\
\hline & & Disagree & 12 & 13.3 & 13.5 & 100.0 & \\
\hline & & Total & 89 & 98.9 & 100.0 & & \\
\hline & Missing & System & 1 & 1.1 & & & \\
\hline & \multicolumn{2}{|l|}{ Total } & 90 & 100.0 & & & \\
\hline \multirow[t]{4}{*}{ Competitiveness } & \multirow[t]{4}{*}{ Valid } & Strongly Agree & 37 & 41.1 & 41.1 & 41.1 & \\
\hline & & Agree & 33 & 36.7 & 36.7 & 77.8 & Agreement \\
\hline & & Undecided & 20 & 22.2 & 22.2 & 100.0 & \\
\hline & & Total & 90 & 100.0 & 100.0 & & \\
\hline Increase market & Valid & Strongly Agree & 57 & 63.3 & 63.3 & 63.3 & \\
\hline \multirow[t]{2}{*}{ Share } & & Agree & 33 & 36.7 & 36.7 & 100.0 & Agreement \\
\hline & & Total & 90 & 100.0 & 100.0 & & \\
\hline \multirow[t]{4}{*}{ Increase profit } & Valid & Strongly Agree & 56 & 62.2 & 62.2 & 62.2 & \\
\hline & & Agree & 28 & 31.1 & 31.1 & 93.3 & Agreement \\
\hline & & Undecided & 6 & 6.7 & 6.7 & 100.0 & \\
\hline & & Total & 90 & 100.0 & 100.0 & & \\
\hline Increase & Valid & Agree & 38 & 42.2 & 42.2 & 42.2 & \\
\hline \multirow[t]{3}{*}{ popularity } & & Undecided & 39 & 43.3 & 43.3 & 85.6 & Unclear \\
\hline & & Disagree & 13 & 14.4 & 14.4 & 100.0 & \\
\hline & & Total & 90 & 100.0 & 100.0 & & \\
\hline
\end{tabular}

The above table shows the reason(s) to which respondents agreed or disagreed that drive them to change their mix strategies. Their agreement is found on the desire (1) to make products new and attractive; (2) offer products at customers' price; (3) to match competition; (4) increase their market share; and (5) to increase profit. While they disagreed on suggestion about building in what customers want, they were uncertain about the idea increasing popularity. 
4. Impacts of marketing mix strategies of soft drink producers on their Consumers:

Table 5: Marketing mix strategies have impact on performance of soft drink producers

\begin{tabular}{|l|l|l|l|l|l|}
\hline & & Frequency & \% & Valid \% & Cumulative \% \\
\hline Valid & Strongly Agree & 41 & 45.6 & 45.6 & 45.6 \\
\cline { 2 - 6 } & Agree & 46 & 51.1 & 51.1 & 96.7 \\
\cline { 2 - 6 } & Undecided & 3 & 3.3 & 3.3 & 100.0 \\
\cline { 2 - 6 } & Total & 90 & 100.0 & 100.0 & \\
\hline
\end{tabular}

The above table shows agreement that marketing mix strategies adopted by the soft drink producers in Anambra State have impact on their performance.

\section{Hypotheses Testing}

$H_{o 1}$ : There is no significant mean difference in the marketing mix frequently used by soft drink producers in Anambra State.

Table 6: Test of significant mean difference in the marketing mix frequently used by soft drink producers in Anambra State

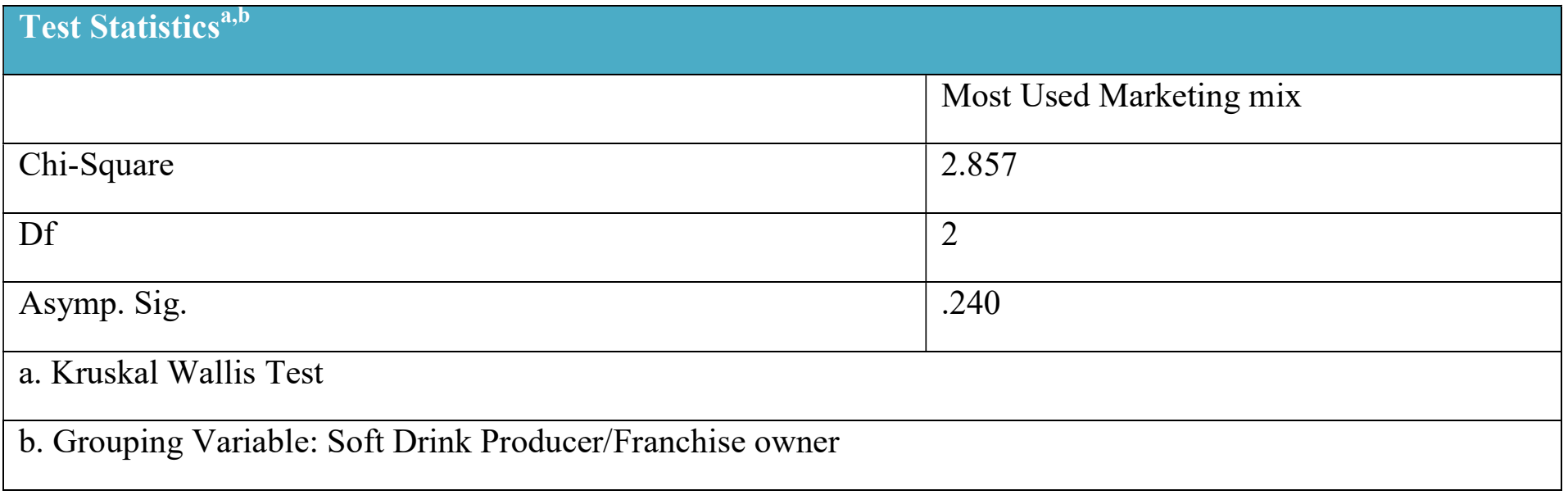

Table 6 above shows results of hypothesis one tests. Since the asymptotic significance value is above 5\% level, we rejected the null hypothesis. The test therefore agrees that there is significant mean difference in the marketing mix frequently used by soft drink producers in Anambra State.

$H_{o 2}$ : There is no significant mean difference on how often soft drink producers in Anambra State change their marketing mix. 
Table 7: Test of significant mean difference on how often soft drink producers in Anambra State change their marketing mix

\begin{tabular}{|l|l|}
\hline \multicolumn{2}{|l|}{ Test Statistics $^{\mathrm{a}, \mathrm{b}}$} \\
\hline Chi-Square & Frequency of Change of Marketing Mix \\
\hline Df & 44.026 \\
\hline Asymp. Sig. & 2 \\
\hline a. Kruskal Wallis Test & .000 \\
\hline b. Grouping Variable: Soft Drink Producer/Franchise owner \\
\hline
\end{tabular}

The asymptotic significance value of hypothesis two tests above is below the 5\% significance level for this study. Therefore we accept that null hypothesis and then conclude that there is no significant mean difference on how often soft drink producers in Anambra State change their marketing mix.

$H_{o 3}:$ There is no significant mean difference in the reasons that prompt change in the marketing mix of soft drink producers in Anambra State.

Table 8: Test of significant mean differences in the reasons that prompt change in the marketing mix of soft drink producers in Anambra State.

\begin{tabular}{|c|c|c|c|c|c|c|c|}
\hline \multicolumn{8}{|c|}{ Test Statistics ${ }^{a, b}$} \\
\hline & $\begin{array}{l}\text { Build-in } \\
\text { what } \\
\text { customers } \\
\text { want }\end{array}$ & $\begin{array}{l}\text { Make } \\
\text { Products } \\
\text { new and } \\
\text { attractive }\end{array}$ & $\begin{array}{l}\text { Offer } \\
\text { products at } \\
\text { customers } \\
\text { price }\end{array}$ & Competitiveness & $\begin{array}{l}\text { Increase } \\
\text { Market } \\
\text { Share }\end{array}$ & $\begin{array}{l}\text { Increase } \\
\text { Profit }\end{array}$ & $\begin{array}{l}\text { Increase } \\
\text { Popularity }\end{array}$ \\
\hline Chi-Square & 1.408 & 1.313 & .020 & 3.399 & 5.394 & 4.203 & 27.521 \\
\hline Df & 2 & 2 & 2 & 2 & 2 & 2 & 2 \\
\hline Asymp. Sig. & .495 & .519 & .990 & .183 & .047 & .122 & .000 \\
\hline \multicolumn{8}{|c|}{ a. Kruskal Wallis Test } \\
\hline \multicolumn{8}{|c|}{ b. Grouping Variable: Soft Drink Producer/Franchise owner } \\
\hline
\end{tabular}

Results of tests of significance of responses on the seven reasons soft drink producers in Anambra State change marketing mix strategies above indicate that the null hypothesis for: build-in what customers want; make products new and attractive; offer product at customers' price; competitiveness; and increase profit be rejected. This means that the soft drink producers in Anambra State have significant differences in their reasons for changing or not changing marketing mix strategies.

On other hand, the test of responses for reasons: increase market share; and increase popularity, do not have 
significant difference. This means that the soft drink producers in Anambra State do not have significant difference in their reasons for changing their marketing mix when it comes to increasing marketing share and popularity.

$\mathrm{H}_{04}$ : There is no significant mean difference on opinions of respondents on whether the marketing mix strategies of soft drink producers have impact on their consumers.

Table 9: Test of the Significant of Impact of Marketing Mix Strategies of Soft Drink Producers in Anambra State.

\begin{tabular}{|l|l|}
\hline \multicolumn{2}{|l|}{ Test Statistics ${ }^{\mathrm{a}, \mathrm{b}}$} \\
\hline Chi-Square & $\begin{array}{l}\text { Marketing mix strategies have impact on performance of } \\
\text { soft drink producers }\end{array}$ \\
\hline Df & 20.925 \\
\hline Asymp. Sig. & 2 \\
\hline a. Kruskal Wallis Test & .000 \\
\hline b. Grouping Variable: Soft Drink Producer/Franchise owner \\
\hline
\end{tabular}

Table 9 shows the test of hypothesis four. Hypothesis four tested for any significant mean difference in the responses of the respondents in Table 5 which showed agreement that marketing mix strategies adopted by the firms have impact on their performance. This result shows the asymptotic significance level to be 0.0001 . Since the asymptotic significance level is below 5\%, we accept the null hypothesis and therefore conclude that marketing mix strategies of soft drink producers have significance impact on their consumers. This implies that marketing mix strategies have significance impact on the performance of all the soft drink producers in Anambra State.

\section{Summary of Findings, Conclusion and Recommendations}

The results from descriptive analyses show that sponsorship in sports and entertainment, diversification, introduction of new brands/products, aggressive advertising and price reduction are the most frequently used marketing mix strategies by soft drink producers in Anambra State. The study also agreed that the soft drink producers in Anambra State change their marketing mix and often too. The reasons for changes in marketing mixes include making their products new and attractive, offer products at customers' asking price, competition in the market, increase of market share, and increase profit.

Results of the hypotheses testing indicated that there is significant mean difference in the marketing mix frequently used by the soft drink producers in Anambra State, but there is no significant mean difference on how often these producers change these mixes.

Further hypotheses tests show that all the soft drink producers in Anambra State pursue the objective of increasing market share as reason for changing marketing mix. Finally, the tests show that marketing mix strategies have significant impact on the performance of all the soft drink producers in Anambra State.

\section{Conclusion}

Based on the results, this study posited that marketing mix strategies have impact on the performance of soft drink producers in Anambra State. These firms have frequently adopted marketing mix strategies like sponsorship in sports and entertainment, diversification, introduction of new brands/products, aggressive advertising and price reduction in order to make products new and attractive, offer products at customers' asking price, remain competitive in the market, increase market share, and increase profit. 


\section{Recommendation}

The study therefore recommended that soft drink producers in Nigeria should adapt to the proven efficaciousness of marketing mix strategies applied in Anambra State. On the other hand, soft drink producers should also get involved in health programmes and more education sponsorships. The researcher believed that health and education programmes would bring about healthy and wealthier consumers and by extension, the general society.

\section{REFERENCES}

1. Akinyele, S.T. (2010). Significance of Strategic Marketing to Enterprise Performance: An Empirical Analysis of Nigerian Oil and Gas Industry. Global Journal of Management and Business Research, 10(6), 60-77.

2. Anyasor, O. M. (2015). Contemporary Basic Marketing. Enugu, Nigeria: Gostak Printing and Pubishing Company Ltd.

3. Aristobulo, J. (1997). From Good Bankers to Bad Bankers: Ineffective Supervision and Management Deterioration as Major Elements in Banking Crisis, EDI Working Papers, World bank Washington.

4. Brownie, D. and Spender, J. C. (1995). Managerial Judgement in Strategic Marketing: Some Preliminary Thoughts. Managerial Decision, 33(6), 39- 58.

5. Ekerete, P. P. (2001). The Effect of Culture on Marketing Strategies of Multinational Firms: A Survey of Selected Multinational Corporations in Nigeria. African Study Monographs, 22(2): 93-101. http://www.africa.kyotou.ac.jp/kiroku/asm_normal/abstracts/pdf/22-2/93101.pdf.

6. Hogarth-Scoth, S., Watson, K., and Wilson, N. (1996). Do Small Business have to Practice Marketing to Survive and Grow? Marketing Intelligence and Planning, 14(1), 6-18.

7. http://en.wikipedia.org/wiki/Competition

8. http://www.mindtools.com/pages/article/newSTR_9 4.htm

9. http://www.thetimes100.co.uk/theory/theory-marketing-mix-\%28price-place-promotionproduct\%29--243.php Retrieved on 20th July, 2011

10. Hunsaker, P. L. (2001). Effects of Formal Strategic Marketing on Financial Performance in Small Firms: A Meta-Analysis. Entrepreneurship Theory and Practice. Chicago II: Dryden Press.

11. Jain, S. (1993). Evolution of strategic marketing. Journal of Business Research, 11(4), 407-425.

12. Jain, S. C. and Punj, G. (1987). Developing Marketing Strategy: A Framework. Marketing Intelligence and Planning, 5(1), 75-89.

13. Johns, F.A.(1990). Successful Market Innovation. European Journal of Innovation Management, 2, 611.

14. Kapferer, J. N. (2004). The New Strategic Brand Management Creating and Sustaining Brand Equity Long Term, 2ed. London and Sterling, VA: Kogan Page.

15. Keller, K. L. (2008). Strategic Brand Management Building, Measuring, and Managing Brand Equity 3ed. Upper Saddle River, NJ: Prentice Hall.

16. Kolter, P. and Armstrong, G. (2006). Principles of Marketing. New Delhi: Prentice-Hall of India Private Ltd.

17. Kotler, P. \& Connor, R.A. (1997). Marketing of Professional Services. Journal of Marketing, 5(4), 12-18.

18. Kotler, P. (1986). Megamarketing. Harvard Business Review, March-April in: http://en.wikipedia.org/wiki/Megamarketing.

19. Li, S., Kinman, R., Duan, Y. and Edwards, J. S. (2000). Computer-Based Support for Marketing Strategy Development. European Journal of Marketing, 34, 5/6.

20. Marketing Mix (4Ps), What is the Marketing Mix? Description

http://www.12manage.com/methodsmarketing mix.html

21. Mavondo, F. T. (2000). Marketing as a Form of Adaptation: Empirical Evidence from a Developing Economy. Marketing Intelligence and Planning, 18(5), 256-272.

22. McCarthy, E. J. (1995). Basic Marketing. New York: D. Irwin.

23. McCarthy, E.J. and Perrault, Jr. W. E. (1984), Basic Marketing: A Managerial Approach. $8^{\text {th }}$ Edition. R.D.Irwin, Homewood, Illinois.

24. McDonald, M. (1989). Strategic Marketing and Firm Performance. Journal of Marketing, 2(4), 2340. 
25. McDonald, M. (1992). Marketing Plans: How to Prepare Them, How to Use Them. Oxford: Butter worth-Heinemann.

26. McDonald, M. (1996). Strategic Marketing Planning. London: Kogan Page.

27. Osuagwu, L. (2001). Adoption of Marketing Strategies in Nigerian Institutions. Academy of Marketing Studies Journal, 5(1), 1-16.

28. Osuagwu, L. (2004). Relationship Marketing Strategies in Nigerian Companies. The Marketing Management Journal, 14(2), 114-128.

29. Pride, W. M. and Ferrell, O. C. (1985). Marketing: Basic Concepts and Decisions. Boston: Houghton Mifflin,

30. Schnars, S. P. (1991). Marketing Strategy. New York: The Free Press. 